\title{
New $[1,2,4]$ triazolo[1,5-a]pyrimidine-7-one corrosion inhibitors for copper in chloride environments
}

\author{
A.A. Kruzhilin, ${ }^{1}$ D D.V. Lyapun, ${ }^{1}$ (D) D.S. Shevtsov, ${ }^{1}$ (iD O.A. Kozaderov, ${ }^{1}{ }^{(D)}$ \\ A.Yu. Potapov, ${ }^{1}$ ID I.D. Zartsyn, ${ }^{1}$ (D) Ch. Prabhakar ${ }^{2}(\mathbb{D}$ \\ and Kh.S. Shikhaliev ${ }^{1}$ (D) \\ ${ }^{1}$ Voronezh State University, Universitetskaya pl. 1, Voronezh, 394018, Russian Federation \\ ${ }^{2}$ National Institute of Technology Kurukshetra, Kurukshetra, 136119, India \\ *E-mail: shikh1961@yandex.ru
}

\begin{abstract}
The article describes a new method for the synthesis of several heterocyclic compounds of the $[1,2,4]$ triazolo[1,5-a]pyrimidine-7-one class. Their structure was proven using NMR spectroscopy and HPLC-MS spectrometry. A series of full-scale natural and electrochemical corrosion tests and quantum-chemical calculations were carried out to study the inhibitory effect of the synthesised substances in relation to copper in neutral and acidic chloride environments within the concentration range of $\sim 0.01-1.00 \mathrm{mM}$. As a result, it was found that the best protective properties were characteristic of inhibitors containing aliphatic branched butyl, phenethyl, isopentyl substituents (the degree of protection is $81 \%, 85 \%$, and $90 \%$ respectively). The protective effect in their presence increases monotonically with an increase in the concentration of the inhibitor within the solubility limits. The results of tests in an acidic chloride environment generally correlate with the corresponding experiments in neutral aqueous solutions. However, there is an insignificant decrease in the degree of protection. This class of compounds might be less effective in case of acid corrosion of metal. The experimental results obtained and the results of quantum-chemical calculations were used to suggest the most probable inhibitory mechanism. This mechanism consists of the chemisorption of inhibitor molecules on the metal surface accompanied by the formation of self-organising protective layers as a result of the complex formation process with participation of endocyclic NH-protons of the dihydropyrimidine cycle.
\end{abstract}

Received: October 11, 2021. Published: October 21, 2021

doi: $\underline{10.17675 / 2305-6894-2021-10-4-7}$

Keywords: copper, corrosion inhibitors, chloride corrosion, triazole derivatives, triazolopyrimidines.

\section{Introduction}

It is very important to find and apply suitable methods for corrosion protection to provide protection and efficient use of metal structures and equipment. Most sectors of both heavy and light industries suffer from various corrosion problems, resulting in serious economic losses $[1,2]$. Using corrosion inhibitors is probably the simplest, most cost-effective, and 
efficient approach to control and combat corrosion, which is commonly used in industry. As a rule, corrosion inhibitors are understood as chemicals or mixtures of substances added to the system in contact with the metal or applied to the surface of the metal, which, at sufficient concentration, interact at the molecular level with the aggressive medium or metal and significantly weaken its corrosion processes [3, 4].

As a rule, corrosion inhibitors are usually classified into inorganic and organic inhibitors. Compared to inorganic inhibitors, organic inhibitors are considered more attractive as they have high passivation efficiency and are environmentally friendly. The inhibitory ability of such compounds is directly due to the peculiarities of their chemical structure and physicochemical properties. Surface passivation is often associated with adsorption and the formation of a protective barrier film of the inhibitor. Organic inhibitors of the heterocyclic compound class are isolated in a separate group. Currently, they are considered to be the highly effective and promising inhibitors to combat corrosion of both ferrous and non-ferrous metals [5].

Derivatives of aminoazoles are some of the most effective heterocyclic corrosion inhibitors [6]. The most common and the most studied azole-type inhibitors include 1,2,3-benzotriazole, its substituted analogues, and 3-aminotriazole derivatives [7]. In this regard, in recent years, scientists have been particularly interested in all sorts of modifications of this heterocyclic matrix aimed at obtaining increasingly effective corrosion inhibitors. From this point of view, the most promising area of research is directed synthesis and the study of condensed biheterocyclic compounds containing a triazole moiety as one of the articulated cycles $[8,9]$.

The authors of [10] focused on new benzo[1,2,4]-triazolo[1,2,4]-triazinone inhibitors and showed that the inhibition effect of such compounds largely depends on their ability to form chelate complexes with copper atoms on the metal's surface due to the presence in their structure of the oxybenzotriazine moiety, a hidden analogue of 8-hydroxyquinoline. In this regard, it is an urgent and promising research task to synthesise and study the properties of such heterocyclic hydroxyderivatives, potentially highly effective chelating compounds, in order to use them as corrosion inhibitors.

The purpose of this work was the synthesis and study of the anticorrosive properties of new heterocyclic $[1,2,4]$ triazolo[1,5- $a$ ]pyrimidine-7-one derivatives containing in their structure a 1- $N-7-\mathrm{COH}$ moiety, whose structure is similar to the structure of the 8-oxyquinoline molecule.

\section{Experimental}

Triazolo[1,5- $a$ ]pyrimidines $\mathbf{a}-\mathbf{i}$ were obtained as a result of the interaction of amitrole or guanazole with the corresponding dicarbonyl compounds. The reaction proceeded mildly and regioselectively and included boiling the reagents in dimethylformamide for an hour. The yields of the reaction products were $>80 \%$. All the obtained compounds were white refractory crystalline substances that were soluble in most organic solvents and were 
partially soluble in water. The synthesis scheme is shown in Figure 1. All reagents and solvents were purchased from commercial suppliers and used without extra treatment.
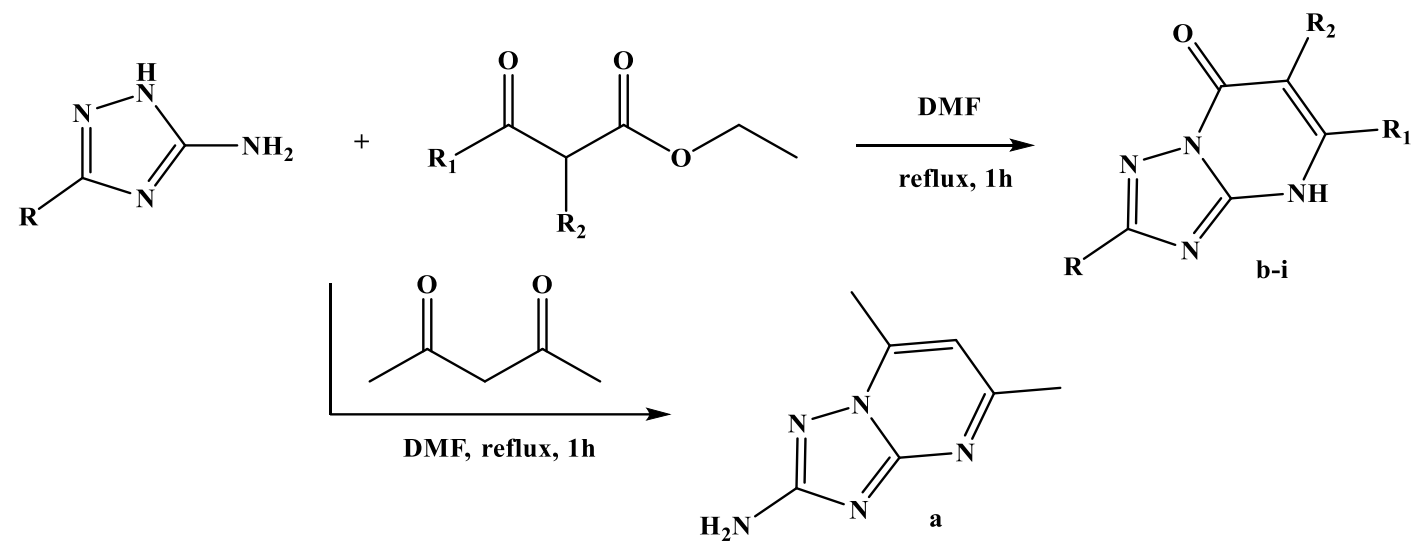

R: $\mathbf{H}(b), \mathrm{NH}_{2}(\mathbf{a}, \mathbf{c}, \mathbf{d}, \mathbf{e}, \mathbf{f}, \mathbf{g}, \mathrm{h}, \mathrm{i})$

$\mathrm{R}_{1}: \mathrm{CH}_{3}(\mathrm{a}, \mathrm{b}, \mathrm{c}, \mathrm{e}, \mathrm{f}, \mathrm{h}, \mathrm{i}),\left(\mathrm{CH}_{3}\right)_{2} \mathrm{CHC}_{2} \mathrm{H}_{4}(\mathrm{~d}), \mathrm{C}_{6} \mathrm{H}_{5}$ (g)

$\mathrm{R}_{2}: \mathrm{H}(\mathrm{a}, \mathrm{b}, \mathrm{c}, \mathrm{d}, \mathrm{g}), \mathrm{C}_{5} \mathrm{H}_{11}(\mathrm{e}), \mathrm{C}_{4} \mathrm{H}_{9}$ (f), $\mathrm{C}_{6} \mathrm{H}_{5} \mathrm{CH}_{2}$ (h), $\mathrm{C}_{6} \mathrm{H}_{5} \mathrm{C}_{2} \mathrm{H}_{4}$ (i)

Figure 1. Inhibitors a-i synthesis scheme.

Synthesis of R,R1,R2-[1,2,4]triazolo[1,5-a]pyrimidines (General method) (a-i)

A mixture of $1 \mathrm{mmol}$ of the corresponding triazole and $1 \mathrm{mmol}$ of the corresponding dicarbonyl compound was refluxed for $1 \mathrm{~h}$ in $3 \mathrm{ml}$ of DMF. The completeness of the reaction was monitored by TLC. The precipitate formed on cooling the solution was filtered off and recrystallized from DMF.

5,7-Dimethyl-[1,2,4]triazolo[1,5-a]pyrimidin-2-amine (a). Yield 81\%, white crystals, m.p. $>300^{\circ} \mathrm{C} .{ }^{1} \mathrm{H}$ NMR spectrum, $\delta$, ppm $(\mathrm{J}, \mathrm{Hz}): 2.45\left(3 \mathrm{H}, \mathrm{s}, \mathrm{CH}_{3}\right) ; 2.56\left(3 \mathrm{H}, \mathrm{s}, \mathrm{CH}_{3}\right) ; 6.20$ $\left(2 \mathrm{H}, \mathrm{s}, \mathrm{NH}_{2}\right) ; 6.80\left(1 \mathrm{H}, \mathrm{s}, \mathrm{CH}_{\mathrm{pyr}}\right)$. Found, $m / z: 164.0932[\mathrm{M}+\mathrm{H}]^{+} . \mathrm{C}_{7} \mathrm{H}_{9} \mathrm{~N}_{5}$. Calculated, $m / z$ : 164.0892 .

5-Methyl-[1,2,4]triazolo[1,5-a]pyrimidin-7(4H)-one (b). Yield 90\%, white crystals, m.p. 276-278 C. ${ }^{1} \mathrm{H}$ NMR spectrum, $\delta$, ppm $(J, \mathrm{~Hz}): 2.32\left(3 \mathrm{H}, \mathrm{s}, \mathrm{CH}_{3}\right) ; 5.83\left(\mathrm{H}, \mathrm{s}, \mathrm{CH}_{\mathrm{pyr}}\right)$; $8.18\left(\mathrm{H}, \mathrm{s}, \mathrm{CH}_{\text {triaz }}\right) ; 13.10-13.50\left(\mathrm{H}\right.$, br. s, NH). Found, $m / z: 151.0346[\mathrm{M}+\mathrm{H}]^{+} . \mathrm{C}_{6} \mathrm{H}_{6} \mathrm{~N}_{4} \mathrm{O}$. Calculated, $m / z: 151.0575$

2-Amino-5-methyl-[1,2,4]triazolo[1,5-a]pyrimidin-7(4H)-one (c). Yield 94\%, white crystals, m.p. $>300^{\circ} \mathrm{C} .{ }^{1} \mathrm{H}$ NMR spectrum, $\delta$, ppm $(\mathrm{J}, \mathrm{Hz}): 2.23\left(3 \mathrm{H}, \mathrm{s}, \mathrm{CH}_{3}\right) ; 5.62(\mathrm{H}, \mathrm{s}$, $\left.\mathrm{CH}_{\mathrm{pyr}}\right) ; 5.89\left(2 \mathrm{H}, \mathrm{s}, \mathrm{NH}_{2}\right) ; 12.20-12.80\left(\mathrm{H}\right.$, br. s, NH). Found, $m / z: 166.0492[\mathrm{M}+\mathrm{H}]^{+}$. $\mathrm{C}_{6} \mathrm{H}_{7} \mathrm{~N}_{5} \mathrm{O}$. Calculated, $m / z: 166.0684$

2-Amino-5-isopentyl-[1,2,4]triazolo[1,5- $a]$ pyrimidin-7(4H)-one $(\boldsymbol{d})$. Yield 88\%, white crystals, m.p. $>300 \mathrm{C}$. ${ }^{1} \mathrm{H}$ NMR spectrum, $\delta$, ppm $(\mathrm{J}, \mathrm{Hz}): 0.89\left(6 \mathrm{H}, \mathrm{d}, \underline{2 \mathrm{CH}_{3}} \mathrm{CHCH}_{2} \mathrm{CH}_{2}\right)$; 1.47-1.58 (3H, m, 2 $\left.2 \mathrm{CH}_{3} \mathrm{CHCH}_{2} \mathrm{CH}_{2}\right) ; 2.48-2.54\left(2 \mathrm{H}, \mathrm{m}, 2 \mathrm{CH}_{3} \mathrm{CHCH}_{2} \mathrm{CH}_{2}\right) ; 5.65(\mathrm{H}, \mathrm{s}$, $\left.\mathrm{CH}_{\text {triaz }}\right) ; 5.96\left(2 \mathrm{H}, \mathrm{s}, \mathrm{NH}_{2}\right) ; 12.50-12.70\left(\mathrm{H}\right.$, br. s, NH). Found, $m / z: 222.1416[\mathrm{M}+\mathrm{H}]^{+}$. $\mathrm{C}_{10} \mathrm{H}_{15} \mathrm{~N}_{5} \mathrm{O}$. Calculated, $m / z: 222.1310$. 
2-Amino-5-methyl-6-pentyl-[1,2,4]triazolo[1,5-a]pyrimidin-7(4H)-one $(\boldsymbol{e})$. Yield 85\%, white crystals, m.p. $>300^{\circ} \mathrm{C}$. ${ }^{1} \mathrm{H}$ NMR spectrum, $\delta$, ppm $(J, \mathrm{~Hz}): 0.87(3 \mathrm{H}, \mathrm{t}, J=7.0$, $\left.\underline{\mathrm{CH}_{3}} \mathrm{CH}_{2} \mathrm{CH}_{2} \mathrm{CH}_{2} \mathrm{CH}\right) ; 1.27-1.41\left(6 \mathrm{H}, \mathrm{m}, \mathrm{CH}_{3} \underline{\mathrm{CH}}_{2} \underline{\mathrm{CH}}_{2} \underline{\mathrm{CH}}_{2} \mathrm{CH}\right) ; 2.26\left(3 \mathrm{H}, \mathrm{s}, \mathrm{CH}_{3}\right) ; 2.38(\mathrm{H}$, $\mathrm{t}, J=7.6, \mathrm{CH}_{3} \mathrm{CH}_{2} \mathrm{CH}_{2} \mathrm{CH}_{2} \mathrm{CH}$ ); $5.83\left(2 \mathrm{H}, \mathrm{s}, \mathrm{NH}_{2}\right) ; 12.10-12.50$ (H, br. s, NH). Found, $m / z$ : $236.2085[\mathrm{M}+\mathrm{H}]^{+}$. $\mathrm{C}_{15} \mathrm{H}_{13} \mathrm{~N}_{5} \mathrm{O}_{4}$. Calculated, $m / z: 236.1467$.

2-Amino-6-butyl-5-methyl-[1,2,4]triazolo[1,5-a]pyrimidin-7(4H)-one $(f)$. Yield 83\%, white crystals, m.p. $>300{ }^{\circ} \mathrm{C} .{ }^{1} \mathrm{H}$ NMR spectrum, $\delta$, ppm $(J, \mathrm{~Hz}): 0.89(3 \mathrm{H}, \mathrm{t}, J=7.1$, $\left.\underline{\mathrm{CH}_{3}} \mathrm{CH}_{2} \mathrm{CH}_{2} \mathrm{CH}\right) ; 1.28-1.39\left(4 \mathrm{H}, \mathrm{m}, \mathrm{CH}_{3} \mathrm{CH}_{2} \mathrm{CH}_{2} \mathrm{CH}\right) ; 2.25\left(3 \mathrm{H}, \mathrm{s}, \mathrm{CH}_{3}\right) ; 2.38(\mathrm{H}, \mathrm{t}, J=7.4$, $\left.\mathrm{CH}_{3} \mathrm{CH}_{2} \mathrm{CH}_{2} \mathrm{CH}\right) ; 5.92\left(2 \mathrm{H}, \mathrm{s}, \mathrm{NH}_{2}\right) ; 12.30-12.50(\mathrm{H}$, br. s, NH). Found, $m / z: 222.1275$ $[\mathrm{M}+\mathrm{H}]^{+} . \mathrm{C}_{10} \mathrm{H}_{15} \mathrm{~N}_{5} \mathrm{O}$. Calculated, $m / z: 222.1310$.

2-Amino-5-phenyl-[1,2,4]triazolo[1,5-a]pyrimidin-7(4H)-one $(\mathrm{g})$. Yield 85\%, white crystals, m.p. $>300{ }^{\circ} \mathrm{C} .{ }^{1} \mathrm{H}$ NMR spectrum, $\delta$, ppm $(\mathrm{J}, \mathrm{Hz}): 6.28\left(\mathrm{H}, \mathrm{s}, \mathrm{CH}_{\text {pyr }}\right) ; 6.35(2 \mathrm{H}, \mathrm{s}$, $\left.\mathrm{NH}_{2}\right) ; 7.50(3 \mathrm{H}, \mathrm{m}$, arom); $7.86(2 \mathrm{H}, \mathrm{m}$, arom); 12.70-13.10 (H, br. s, NH). Found, $m / z$ : $228.0879[\mathrm{M}+\mathrm{H}]^{+} . \mathrm{C}_{11} \mathrm{H}_{9} \mathrm{~N}_{5} \mathrm{O}$. Calculated, $m / z: 228.0841$.

2-Amino-6-benzyl-5-methyl-[1,2,4]triazolo[1,5-a]pyrimidin-7(4H)-one $(\boldsymbol{h})$. Yield 92\%, white crystals, m.p. $>300{ }^{\circ} \mathrm{C} .{ }^{1} \mathrm{H}$ NMR spectrum, $\delta$, ppm $(\mathrm{J}, \mathrm{Hz}): 2.25\left(3 \mathrm{H}, \mathrm{s}, \mathrm{CH}_{3}\right)$; $3.79(\mathrm{H}, \mathrm{s}, \underline{\mathrm{CHPh}}) ; 5.91\left(2 \mathrm{H}, \mathrm{s}, \mathrm{NH}_{2}\right) ; 7.15-7.25(5 \mathrm{H}, \mathrm{m}$, arom $) ; 12.30-12.70$ (H, br. s, NH). Found, $m / z: 256.1269[\mathrm{M}+\mathrm{H}]^{+} . \mathrm{C}_{13} \mathrm{H}_{13} \mathrm{~N}_{5} \mathrm{O}$. Calculated, $m / z: 256.1154$.

2-Amino-5-methyl-6-phenethyl-[1,2,4]triazolo[1,5-a]pyrimidin-7(4H)-one (i). Yield $81 \%$, white crystals, m.p. $>300{ }^{\circ} \mathrm{C} .{ }^{1} \mathrm{H}$ NMR spectrum, $\delta$, ppm $(\mathrm{J}, \mathrm{Hz}): 2.04\left(3 \mathrm{H}, \mathrm{s}, \mathrm{CH}_{3}\right)$; 2.65-2.71 (3H, m, $\left.\underline{\mathrm{CHCH}}_{2} \mathrm{Ph}\right) ; 5.90\left(2 \mathrm{H}, \mathrm{s}, \mathrm{NH}_{2}\right) ; 7.17-7.29(5 \mathrm{H}, \mathrm{m}$, arom); 12.20-12.50 $\left(\mathrm{H}\right.$, br. s, NH). Found, $m / z: 270.1599[\mathrm{M}+\mathrm{H}]^{+} . \mathrm{C}_{14} \mathrm{H}_{15} \mathrm{~N}_{5} \mathrm{O}$. Calculated, $m / z: 270.1247$.

Structural formulas and solubility of the studied substances in water are presented in Table 1.

Table 1. Inhibitor names, structures and solubility in water.

\begin{tabular}{|c|c|c|}
\hline Code & Formula & 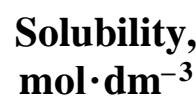 \\
\hline $\mathrm{a}$ & $\begin{array}{l}\text { 5,7-dimethyl- } \\
{[1,2,4] \text { triazolo[1,5- }} \\
\text { a]pyrimidin-2-amine }\end{array}$ & $\geq 10^{-3}$ \\
\hline $\mathrm{b}$ & $\begin{array}{l}\text { 5-methyl- }[1,2,4] \text { triazolo } \\
{[1,5-a] \text { pyrimidin-7(4H)-one }}\end{array}$ & $\geq 10^{-3}$ \\
\hline $\mathrm{c}$ & $\begin{array}{c}\text { 2-amino-5-methyl- } \\
{[1,2,4] \text { triazolo }[1,5-} \\
\text { a]pyrimidin-7(4H)-one }\end{array}$ & $\geq 10^{-3}$ \\
\hline
\end{tabular}




\begin{tabular}{|c|c|c|c|}
\hline Code & Name & Formula & $\begin{array}{l}\text { Solubility, } \\
\mathbf{m o l} \cdot \mathbf{d m}^{-3}\end{array}$ \\
\hline d & $\begin{array}{c}\text { 2-amino-5-isopentyl- } \\
{[1,2,4] \text { triazolo }} \\
{[1,5-a] \text { pyrimidin- } 7(4 H) \text {-one }}\end{array}$ & & $\leq 7 \cdot 10^{-4}$ \\
\hline e & $\begin{array}{c}\text { 2-amino-5-methyl-6-pentyl- } \\
{[1,2,4] \text { triazolo }[1,5-} \\
\text { a]pyrimidin-7 }(4 H) \text {-one }\end{array}$ & & $\leq 8 \cdot 10^{-4}$ \\
\hline $\mathrm{f}$ & $\begin{array}{l}\text { 2-amino-6-butyl-5-methyl- } \\
{[1,2,4] \text { triazolo }} \\
{[1,5-a] \text { pyrimidin- } 7(4 H) \text {-one }}\end{array}$ & & $\leq 10^{-4}$ \\
\hline g & $\begin{array}{c}\text { 2-amino-5-phenyl- } \\
{[1,2,4] \text { triazolo }} \\
{[1,5-a] \text { pyrimidin- } 7(4 H) \text {-one }}\end{array}$ & & $\leq 6 \cdot 10^{-5}$ \\
\hline $\mathrm{h}$ & $\begin{array}{c}\text { 2-amino-6-benzyl-5-methyl- } \\
{[1,2,4] \text { triazolo }} \\
{[1,5-a] \text { pyrimidin- }(4 H) \text {-one }}\end{array}$ & & $\leq 7 \cdot 10^{-5}$ \\
\hline $\mathrm{i}$ & $\begin{array}{c}\text { 2-amino-5-methyl-6- } \\
\text { phenethyl- }[1,2,4] \text { triazolo } \\
{[1,5-a] \text { pyrimidin-7 }(4 H) \text {-one }}\end{array}$ & & $\geq 10^{-3}$ \\
\hline
\end{tabular}

To evaluate the efficiency of the corrosion inhibition properties of the studied compounds, a set of electrochemical and field corrosion testing methods was used. Quantum-chemical calculations were also performed.

Electrochemical measurements were performed at room temperature $\left(\sim 25^{\circ} \mathrm{C}\right)$ on copper (M1) (copper content not less than 99.9\%) electrodes in an unstirred borate buffer aqueous solution ( $\mathrm{pH} 7.4$ ) with natural aeration, in the presence of the inhibitor and $10 \mathrm{mM}$ $\mathrm{NaCl}$. A classical electrolytic three-electrode cell without separation of anode and cathode compartments was used in order to accelerate transient measurements.

A saturated silver chloride reference electrode was placed in a separate container linked to the electrolytic cell by an agar-agar-based salt bridge filled with a potassium nitrate saturated solution. The auxiliary electrode was a platinum gauze. The working copper electrode was polished by K3000 sandpaper, degreased in 96\% ethanol, and washed with distilled water. The potentials of the working electrode $(E)$ are given according to the standard hydrogen electrode (SHE) scale. The current density $i$ was calculated by dividing the actual current $I$ by the geometric area of the working electrode $\left(0.75 \mathrm{~cm}^{2}\right)$.

Electrochemical measurements were performed using an IPC-PRO potentiostat. In order to remove an oxide film, the working $\mathrm{Cu}$-electrode was cathodically pre-polarised at $E=-0.60 \mathrm{~V}$ for $15 \mathrm{~min}$ prior to the experiment. The electrode was then held in the solution 
for about 3 to 5 minutes until the corrosion potential $\left(E_{\text {cor }}\right)$ stabilized. An $\mathrm{NaCl}$ solution was then added to the working solution while stirring, so that the concentration of chloride ions would be $C_{\mathrm{Cl}^{-}}=10 \mathrm{mM}$. The studied inhibitors were also added to the solution at concentrations of $C_{\text {inh }}=0.01,0.10$ and $1.00 \mathrm{mM}$. After the new $E_{\text {cor }}$ value was established, the polarization curve was registered by scanning the potential towards either the anode or the cathode at $0.2 \mathrm{mV} / \mathrm{sec}$. The activation potential $\left(E_{\text {act }}\right)$ was identified by a rapid increase in the current on the anode polarization curve. Pits were then visually identified on the surface of the electrode. The measurement error for $E_{\text {act }}$ was below $0.03 \mathrm{~V}$.

The rate of corrosion in current units $\left(i_{\text {cor }}\right)$ was determined by the polarization resistance technique as summarized by Mansfeld [12].

The effectiveness of the inhibition activity of the obtained inhibitors was evaluated by the degree of protection

$$
Z_{\mathrm{i}}=\frac{i_{\mathrm{cor}, 0}-i_{\mathrm{cor}, \mathrm{inh}}}{i_{\mathrm{cor}, 0}} \cdot 100 \%
$$

where $i_{\text {cor }, 0}$ and $i_{\text {cor,inh }}$ - are the corrosion current densities with and without an inhibitor respectively.

A field corrosion testing was carried out on copper plates with a surface area of $S=20 \times 50 \mathrm{~mm}^{2}$ and a thickness of $d=0.10 \mathrm{~mm}$, which were preliminarily polished with K3000 sandpaper and degreased in acetone.

The experiments that lasted for $t=7$ days were carried out on three samples in an unstirred naturally aerated $1 \% \mathrm{HCl}$ solution. The plates were then washed with distilled water and treated according to GOST 9.907-83 "Methods for the removal of corrosion products after corrosion tests". The corrosion rate was determined according to the weight loss of the samples and calculated using the equation:

$$
k_{\mathrm{inh}}=\frac{m_{0}-m}{S \cdot t}
$$

where $m_{0}$ and $m$ are the weight of the sample before and after the corrosion tests, respectively; $S$ is the total area of the plate, $\mathrm{m}^{2}$; and $t$ is the experiment time, days.

The inhibition efficiency of triazolo [1,5-a]pyrimidinones was evaluated by the value of the inhibition factor:

$$
\gamma=\frac{k_{0}}{k_{\text {inh }}}
$$

and by the degree of protection:

$$
Z_{\mathrm{k}}=\frac{k_{0}-k_{\mathrm{inh}}}{k_{0}} \cdot 100 \%
$$

where $k_{0}$ and $k_{\text {inh }}$ are the rates of corrosion in the $\mathrm{HCl}$ solution with and without the inhibitor respectively. The parameter $k_{0}$ averaged $19.2 \mathrm{~g} \cdot \mathrm{m}^{-2} \cdot \mathrm{day}^{-1}$. 
All the synthesized molecules and their isomeric (tautomeric) forms (except $\mathbf{f}$ ) are fully optimized using density functional theory (DFT) with B3LYP functional using 6-31G $(\mathrm{d}, \mathrm{p})$ basis set in Gaussian soft [13]. The optimized geometries show non-negative frequencies which results in molecules are located at minimum energy in potential energy surface. The determination of HOMO, LUMO energies and energy gap along with ionization potential, electron affinity, electronegativity $(\chi)$, absolute hardness $(\eta)$ and softness $(\sigma)$ for all the molecules were carried out at same level of theory.

From density functional theory the absolute hardness $(\eta)$ is defined as [14]

$$
\eta=\frac{1}{2} \cdot \frac{\partial \mu}{\partial N}=\frac{1}{2} \cdot \frac{\partial^{2}}{\partial N^{2}}
$$

where $\mu$ is the chemical potential and $N$ is the number of electron and $E$ is the energy. R.G. Pearson has proposed an operational definition for absolute hardness as

$$
\eta=\frac{I P-E A}{2}
$$

where $I P$ and $E A$ are ionization energy and electron affinity, respectively. Also, from Koopman's theorem, $I P$ and $E A$ are defined as

$$
I P=-E_{\mathrm{HOMO}} ; \quad E A=-E_{\mathrm{LUMO}}
$$

$E_{\mathrm{HOMO}}$ and $E_{\mathrm{LUMO}}$ are the energies of highest occupied and lowest unoccupied molecular orbitals. Thus, the hardness $(\eta)$ is a measure of resistance to change of electron cloud of chemical system. The softness $(\sigma)$ is reciprocal of the hardness, and it is an important parameter of reaction chemistry as most of the reactive species have higher softness value. Electronegativity $(\chi)$ is defined in terms of energies of HOMO and LUMO as

$$
\chi=\frac{I P+E A}{2}
$$

\section{Results and Discussion}

A series of potentiodynamic studies were conducted to obtain averaged test results. The detailed calculations are presented in Table 2. The obtained polarisation curves are shown in Figures 2, 3 .

Using triazolopyrimidinones $\mathbf{a}, \mathbf{b}, \mathbf{c}, \mathbf{e}, \mathbf{g}$, and $\mathbf{h}$ as corrosion inhibitors for copper in a neutral chloride environment resulted in a shift of the free corrosion potential to the cathode region in the entire concentration range. The shift reached $80 \mathrm{mV}$. The free corrosion potential was most influenced by compounds $\mathbf{a}$ and $\mathbf{c}$. Thus, compounds $\mathbf{a}, \mathbf{b}, \mathbf{c}, \mathbf{e}, \mathbf{g}$, and $\mathbf{h}$ can be considered as cathodic inhibitors.

The other studied compounds $\mathbf{d}, \mathbf{f}$, and $\mathbf{i}$ had a mixed effect on the free corrosion potential. In some cases, a shift of $E_{\text {cor }}$ was practically absent (at $C_{\mathrm{inh}}=0,1 \mathrm{mM}$ of inhibitors $\mathbf{d}$ and f) or there was an insignificant deviation by $10-30 \mathrm{mV}$ both in the cathode and anode regions. It is advisable to consider compounds $\mathbf{d}, \mathbf{f}$, and $\mathbf{i}$ as substances acting as mixed inhibitors $[15,16]$. 
Table 2. Open circuit potential, polarization resistance, corrosion current density, and degree of protection of copper electrode in $0.01 \mathrm{M} \mathrm{NaCl}$ solutions with different derivatives of benzo-[1,2,4]-triazolo-[1,2,4]triazinones.

\begin{tabular}{|c|c|c|c|c|c|}
\hline Inhibitor & $\begin{array}{c}\text { Inhibitor } \\
\text { concentration, } \\
C_{\text {inh, }}, \mathbf{m M}\end{array}$ & $\begin{array}{c}\text { Corrosion } \\
\text { potential, } \\
E_{\text {cor, }}, \mathrm{V}\end{array}$ & $\begin{array}{c}\text { Polarization } \\
\text { resistance, } \\
R_{\mathrm{p}}, \mathrm{k} \Omega \cdot \mathrm{cm}^{2}\end{array}$ & 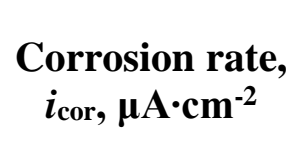 & $\begin{array}{c}\text { Degree of } \\
\text { protection, } \\
Z_{\mathrm{i}, \%}\end{array}$ \\
\hline none & - & 0.172 & $41.9 \pm 4.6$ & $1.2 \pm 0.3$ & - \\
\hline \multirow{3}{*}{$\mathrm{a}$} & 0.010 & 0.095 & $7.9 \pm 1.4$ & $2.4 \pm 0.7$ & -100.0 \\
\hline & 0.100 & 0.097 & $7.3 \pm 1.6$ & $2.4 \pm 0.9$ & -100.0 \\
\hline & 1.000 & 0.105 & $8.0 \pm 1.5$ & $2.3 \pm 0.5$ & -91.7 \\
\hline \multirow{3}{*}{$\mathrm{b}$} & 0.010 & 0.171 & $21.1 \pm 6.6$ & $2.9 \pm 0.9$ & -141.7 \\
\hline & 0.100 & 0.133 & $21.2 \pm 6.3$ & $2.7 \pm 0.6$ & -125.0 \\
\hline & 1.000 & 0.097 & $15.4 \pm 3.7$ & $2.1 \pm 0.5$ & -75.0 \\
\hline \multirow{3}{*}{$\mathrm{c}$} & 0.010 & 0.127 & $44.3 \pm 14.7$ & $1.0 \pm 0.3$ & 16.7 \\
\hline & 0.100 & 0.135 & $17.3 \pm 1.6$ & $2.3 \pm 0.7$ & -91.7 \\
\hline & 1.000 & 0.092 & $30.1 \pm 1.3$ & $1.4 \pm 0.4$ & -16.7 \\
\hline \multirow{3}{*}{$\mathrm{d}$} & 0.007 & 0.204 & $70 \pm 18$ & $0.42 \pm 0.07$ & 65.0 \\
\hline & 0.070 & 0.170 & $235 \pm 67$ & $0.14 \pm 0.03$ & 88.3 \\
\hline & 0.700 & 0.180 & $257 \pm 54$ & $0.11 \pm 0.03$ & 90.8 \\
\hline \multirow{3}{*}{$\mathrm{e}$} & 0.008 & 0.156 & $11.9 \pm 2.4$ & $2.8 \pm 0.5$ & -133.3 \\
\hline & 0.080 & 0.171 & $57.3 \pm 12.7$ & $0.50 \pm 0.17$ & 58.3 \\
\hline & 0.800 & 0.094 & $78.1 \pm 17.9$ & $0.23 \pm 0.05$ & 80.8 \\
\hline \multirow{2}{*}{$\mathrm{f}$} & 0.010 & 0.164 & $117 \pm 11$ & $0.41 \pm 0.12$ & 65.8 \\
\hline & 0.100 & 0.178 & $121 \pm 5$ & $0.22 \pm 0.06$ & 81.7 \\
\hline \multirow{2}{*}{$\mathrm{g}$} & 0.006 & 0.124 & $50.5 \pm 17.1$ & $1.0 \pm 0.2$ & 16.7 \\
\hline & 0.060 & 0.151 & $50.6 \pm 14.4$ & $0.44 \pm 0.13$ & 63.3 \\
\hline \multirow{2}{*}{$\mathrm{h}$} & 0.007 & 0.126 & $131 \pm 18$ & $0.39 \pm 0.08$ & 67.5 \\
\hline & 0.070 & 0.169 & $92.3 \pm 17.2$ & $0.30 \pm 0.07$ & 75.0 \\
\hline \multirow{3}{*}{$\mathrm{i}$} & 0.010 & 0.200 & $64.6 \pm 19.8$ & $0.64 \pm 0.16$ & 46.7 \\
\hline & 0.100 & 0.148 & $184 \pm 37$ & $0.19 \pm 0.05$ & 84.1 \\
\hline & 1.000 & 0.187 & $227 \pm 10$ & $0.17 \pm 0.06$ & 85.8 \\
\hline
\end{tabular}

A number of regularities can be distinguished as a result of the analyses of the shape and nature of the polarisation curves. For example, compounds $\mathbf{a}, \mathbf{b}$, and $\mathbf{c}$ are characterised by increased current density in all sections of the curves compared to the background curve. 
The peak current density in the anode sections is formed at lower values of the electrode potential. For compounds $\mathbf{e}, \mathbf{g}$, and $\mathbf{h}$ the activation potential shifts to the anode region by $50-200 \mathrm{mV}$ relative to the test experiment. The corrosion current is significantly reduced relative to the similar value in the background solution only at a concentration of inhibitors of $\geq 0.1 \mathrm{mM}$. The calculated indicators of the degree of protection for these inhibitors reach $80 \%$ at the maximum studied concentration. The anodic polarisation curves for triazolopyrimidinones $\mathbf{d}, \mathbf{f}$, and $\mathbf{i}$ have a shift of the activation potential by $100-200 \mathrm{mV}$ to the cathode region (at $C_{\mathrm{inh}} \geq 0.1 \mathrm{mM}$ ). Moreover, in case of the $\mathbf{f}$ and $\mathbf{i}$ derivatives there is a significant shift of the peak current density to more positive potentials. The current density is reduced by $20-30 \%$. The calculated values of the degree of protection up to $85-90 \%$ at $C_{\text {inh }} \geq 1.0 \mathrm{mM}$ correspond to a high inhibitory effect.

Generally, the degree of protection monotonously grew with an increase in the concentration of the inhibitor. The greatest inhibition effect was observed in the presence of triazolopyrimidines (compounds $\mathbf{d}$ and $\mathbf{i}$ ). When $C_{\mathrm{inh}}=1.00 \mathrm{mM}$, the degree of protection was up to $90 \%$ and $85 \%$ respectively. High values were also observed when using compounds $\mathbf{g}$ and $\mathbf{h}$. However, the low solubility of these compounds in water significantly limits the possibility of their application for protecting metals.
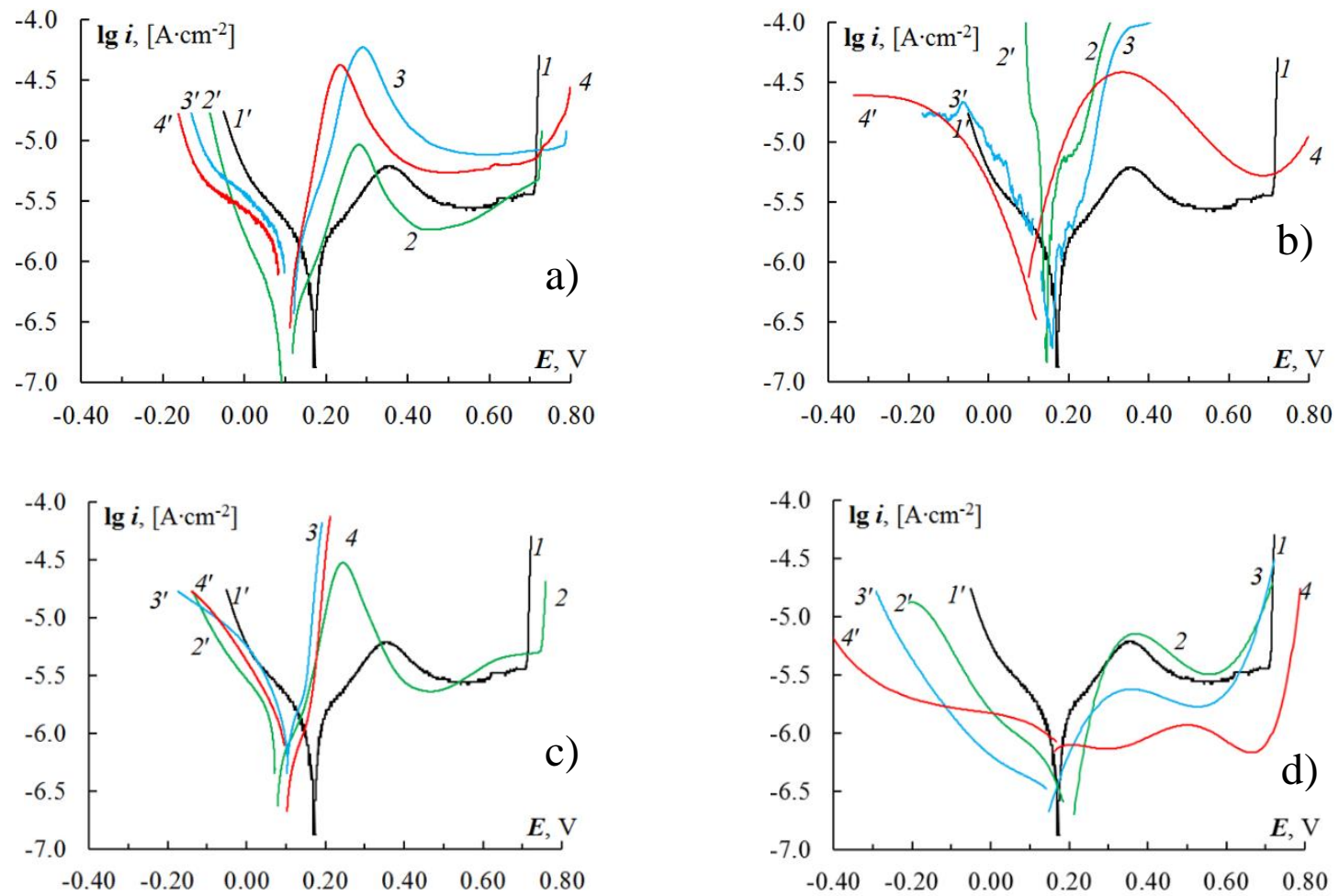

Figure 2. Anodic $(1-4)$ and cathodic $\left(1^{\prime}-4^{\prime}\right)$ polarization curves of copper in borate buffer $(\mathrm{pH} 7.4)+10 \mathrm{mM} \mathrm{NaCl}$ without an inhibitor $\left(1,1^{\prime}\right)$ and in the presence of 5,7-dimethyl-[1,2,4]triazolo[1,5-a]pyrimidin-2-amine (a), 5-methyl-[1,2,4]triazolo[1,5- $a$ ]pyrimidin-7(4H)-one (b) at concentrations of 0.01 (2), 0.10 (3), and $1.00 \mathrm{mM}$ (4), 2-amino-5-methyl-[1,2,4]triazolo[1,5a]pyrimidin-7(4H)-one (c), 2-amino-5-isopentyl-[1,2,4]triazolo[1,5- $a]$ pyrimidin-7(4H)-one (d). 

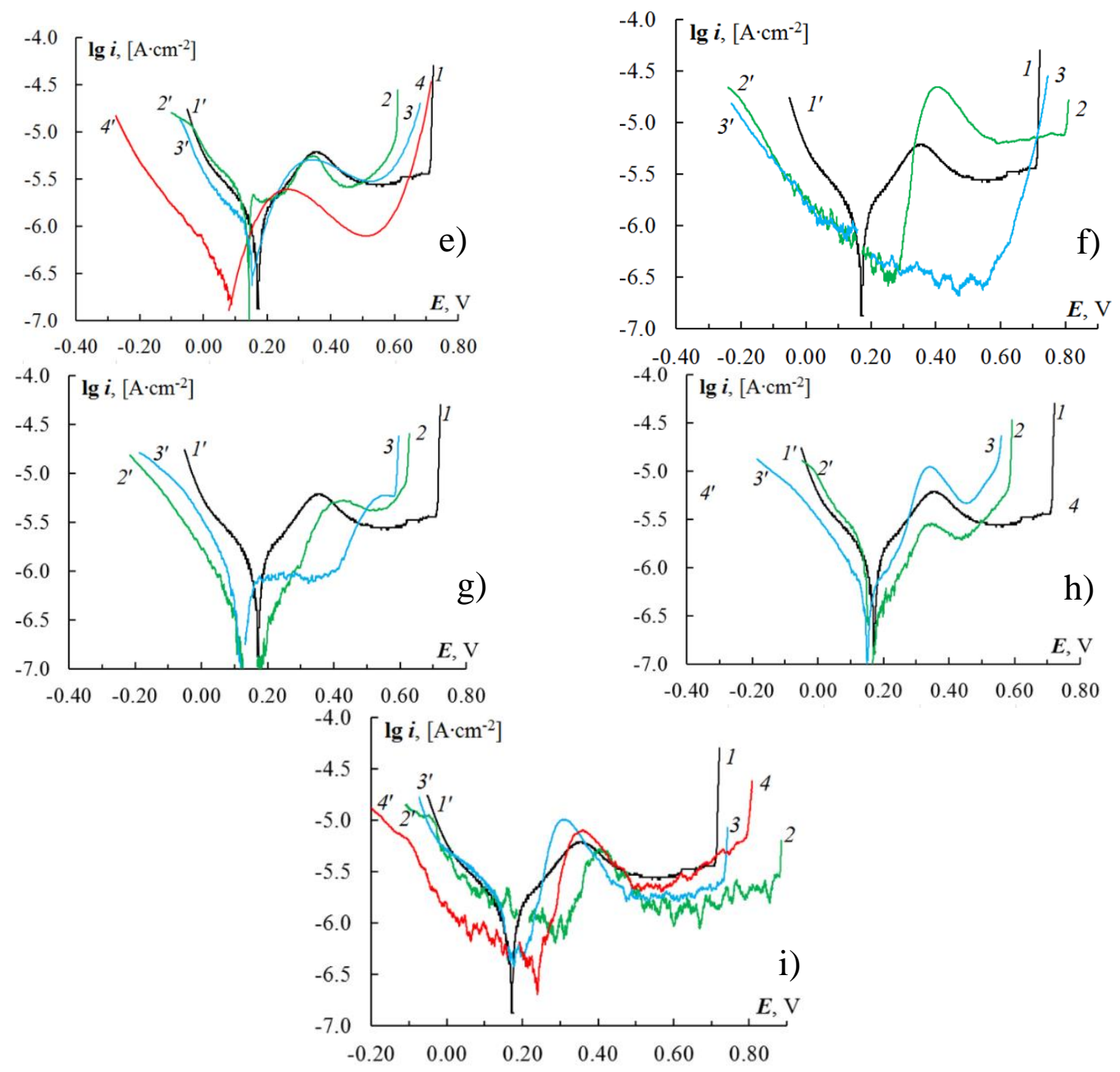

Figure 3. Anodic $(1-4)$ and cathodic $\left(1^{\prime}-4^{\prime}\right)$ polarization curves of copper in borate buffer $(\mathrm{pH} 7.4)+10 \mathrm{mM} \mathrm{NaCl}$ without an inhibitor $\left(1,1^{\prime}\right)$ and in the presence of 2-amino-5-methyl-6pentyl-[1,2,4]triazolo[1,5-a]pyrimidin-7(4H)-one (e), 2-amino-6-butyl-5-methyl-

$[1,2,4]$ triazolo[1,5-a]pyrimidin-7(4H)-one (f), 2-amino-5-phenyl-[1,2,4]triazolo[1,5a]pyrimidin-7(4H)-one (g), 2-amino-6-benzyl-5-methyl-[1,2,4]triazolo[1,5-a]pyrimidin-7(4H)one (h) and 2-amino-5-methyl-6-phenethyl-[1,2,4]triazolo[1,5- $a]$ pyrimidin-7(4H)-one (i) at concentrations of 0.01 (2), 0.10 (3), and $1.00 \mathrm{mM}(4)$.

The results of the tests in an acidic chloride environment (Table 3) are similar to the experiments in neutral aqueous electrolyte solutions. Similarly, an increase in the protective properties was observed with an increase in the $C_{\text {inh }}$ in the studied solutions. Values of $Z_{\mathrm{k}}$ obtained during gravimetric tests correlate with the corresponding values of $Z_{\mathrm{i}}$. There was a slight decrease in the indicator of the degree of protection. Apparently, the studied class of compounds is less effective in the case of acidic corrosion of metals relative to neutral 
environments. An increase in the protective properties of inhibitors was observed in the following series: $\mathbf{b}-\mathbf{a}-\mathbf{c}-\mathbf{g}-\mathbf{h}-\mathbf{e}-\mathbf{f}-\mathbf{i}-\mathbf{d}$.

Table 3. Results of the copper natural corrosion tests.

\begin{tabular}{|c|c|c|c|c|}
\hline Inhibitor & $\begin{array}{l}\text { Concentration of } \\
\text { inhibitor, } C_{\mathrm{inh}}, \mathrm{mM}\end{array}$ & $\begin{array}{c}\text { Corrosion rate, } \\
k, \mathrm{~g} \cdot \mathrm{m}^{2} \cdot \mathrm{day}^{-1}\end{array}$ & $\begin{array}{l}\text { Inhibition } \\
\text { coefficient, } \gamma\end{array}$ & $\begin{array}{c}\text { Degree of } \\
\text { protection, } Z_{k}, \%\end{array}$ \\
\hline none & - & 19.2 & 1.0 & 0.0 \\
\hline \multirow{3}{*}{$\mathbf{a}$} & 0.010 & 18.2 & 1.1 & 5.4 \\
\hline & 0.100 & 18.0 & 1.1 & 6.3 \\
\hline & 1.000 & 16.2 & 1.2 & 15.6 \\
\hline \multirow{3}{*}{ b } & 0.010 & 18.9 & 1.0 & 1.5 \\
\hline & 0.100 & 17.9 & 1.1 & 6.7 \\
\hline & 1.000 & 16.9 & 1.1 & 7.7 \\
\hline \multirow{3}{*}{ c } & 0.010 & 20.2 & 1.0 & -4.9 \\
\hline & 0.100 & 18.0 & 1.1 & 6.3 \\
\hline & 1.000 & 15.8 & 1.2 & 17.6 \\
\hline \multirow{3}{*}{ d } & 0.007 & 12.3 & 1.6 & 36.0 \\
\hline & 0.070 & 6.6 & 2.9 & 65.7 \\
\hline & 0.700 & 6.1 & 3.2 & 68.3 \\
\hline \multirow{3}{*}{ e } & 0.008 & 19.7 & 1.0 & -2.4 \\
\hline & 0.080 & 9.4 & 2.0 & 51.2 \\
\hline & 0.800 & 5.2 & 3.7 & 73.0 \\
\hline \multirow{2}{*}{ f } & 0.010 & 7.2 & 2.7 & 62.6 \\
\hline & 0.100 & 5.1 & 3.8 & 73.5 \\
\hline \multirow{2}{*}{$\mathbf{g}$} & 0.006 & 12.7 & 1.5 & 34.0 \\
\hline & 0.060 & 10.4 & 1.8 & 45.9 \\
\hline \multirow{2}{*}{ h } & 0.007 & 11.9 & 1.6 & 38.1 \\
\hline & 0.070 & 11.0 & 1.7 & 42.8 \\
\hline \multirow{3}{*}{$\mathbf{i}$} & 0.010 & 11.8 & 1.6 & 38.7 \\
\hline & 0.100 & 6.9 & 2.8 & 64.1 \\
\hline & 1.000 & 5.5 & 3.5 & 71.4 \\
\hline
\end{tabular}

It is noteworthy that during the transition from 5,7-dimethyl-triazolopyrimidine-2amine $\mathbf{a}$ to oxo derivatives $\mathbf{b}$ and $\mathbf{c}$ there was no positive effect on the copper protection: all 
compounds contributed to an increase in the current density on the polarisation curves, the peak corrosion currents significantly exceeded their value in the background solution. Direct corrosion tests also indicated a low inhibitory effect. This means that both the keto group and exocyclic amino groups do not play a significant role in the passivation mechanism of non-ferrous metals by this class of compounds. Consequently, the interaction of these substances with the metal surface is possible due to the presence of endocyclic NH-protons in the structure of molecules. The chelation effect expected at the stage of molecular design of inhibitors was not observed.

To understand the mechanism of metal passivation with the studied compounds, it is also very important to determine the probability of the existence of these substances in various tautomeric forms in aqueous solutions. The calculations of relative energies as well as optimised structures of molecules and their tautomers are shown in Figures 4, 5. The obtained values of the total energy correspond to the fact that ketone taumeric forms are the most favourable for all substances. The energy gains in relation to the corresponding enols was $\sim 3-6 \mathrm{kcal} / \mathrm{mol}(\sim 8-12 \mathrm{kcal} / \mathrm{mol}$ for enols with reversed arrangement of $\mathrm{OH}$-protons).

RE REcture RE


Figure 4. Optimized structures and relative energy (RE, in $\mathrm{kcal} / \mathrm{mol}$ ) of the $\mathbf{b}-\mathbf{e}$ tautomers obtained at B3LYP/6-311+G (d, p) level of theory.

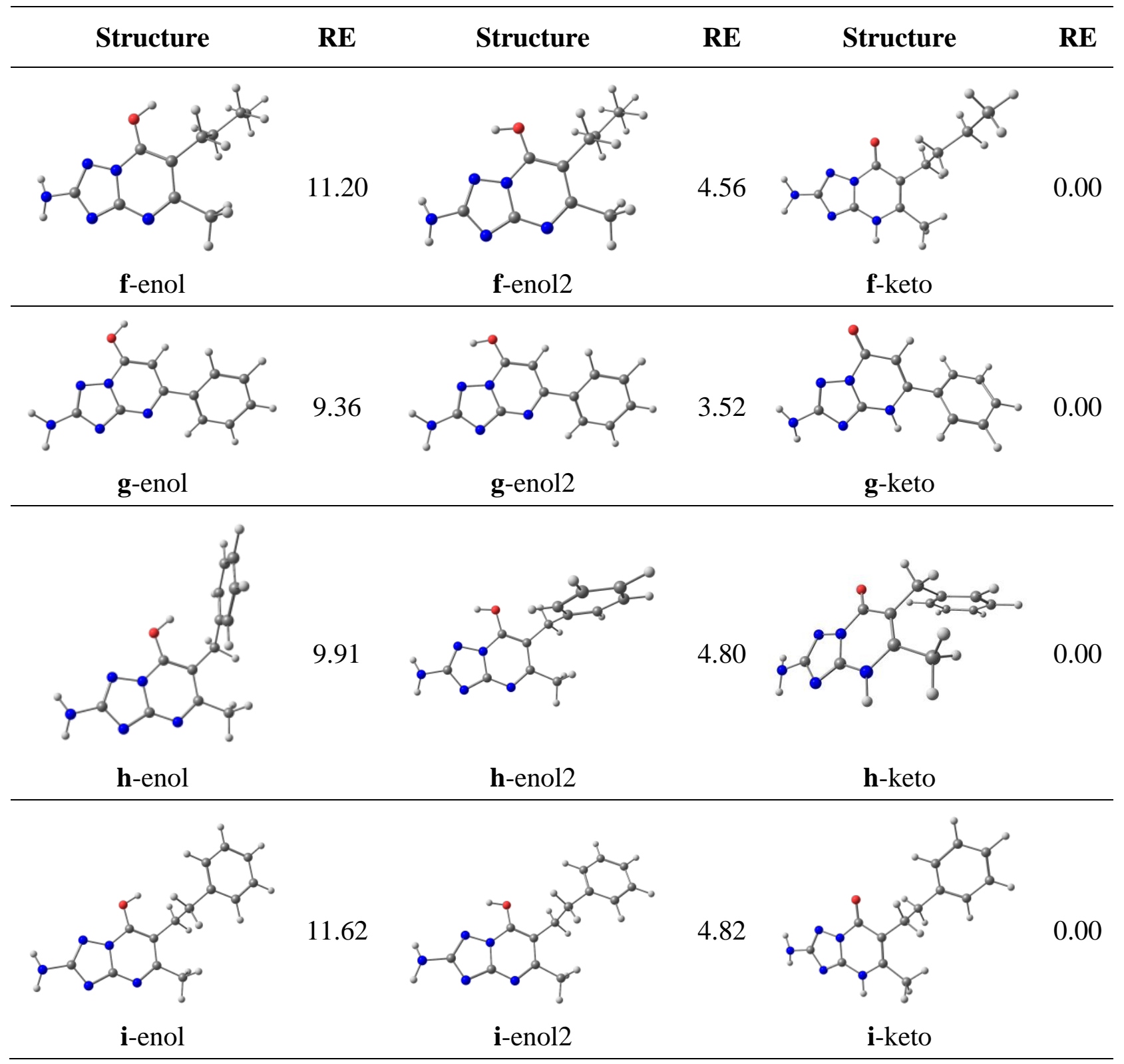

Figure 5. Optimized structures and relative energy (RE, in $\mathrm{kcal} / \mathrm{mol}$ ) of the $\mathbf{f}-\mathbf{i}$ tautomers obtained at B3LYP/6-311+G (d, p) level of theory (continued).

It is known that the ability of inhibitors to interact with a metal surface increases with an increase in HOMO and a decrease in LUMO [21]. The smaller the HOMO-LUMO gap the higher the reactivity of the inhibitor in relation to the metal surface and the stronger the inhibitory effect. The calculated HOMO, LUMO energies, HOMO-LUMO gap (HLG), ionisation potential, electron affinity, electronegativity $(\chi)$, and absolute hardness $(\eta)$ and softness $(\sigma)$ in $\mathrm{eV}$ are given in Table 4. Molecular orbital patterns for all molecules are shown in Figures 6, 7. 
Table 4. Calculated HOMO, LUMO energies, HOMO-LUMO gap (HLG), Ionization Potential (IP), Electron Affinity $(E A)$, Electronegativity $(\chi)$, Absolute Hardness $(\eta)$ and Softness $(\sigma)$ in eV at B3LYP/6$311+\mathrm{G}(\mathrm{d}, \mathrm{p})$ level of theory.

\begin{tabular}{|c|c|c|c|c|c|c|c|c|}
\hline Name & HOMO & LUMO & HLG & $I P$ & $\boldsymbol{E A}$ & $\chi$ & $\eta$ & $\boldsymbol{\sigma}$ \\
\hline $\mathbf{a}$ & -6.31 & -1.52 & 4.79 & 6.31 & 1.52 & 3.91 & 2.40 & 0.42 \\
\hline b-enol & -6.97 & -1.53 & 5.44 & 6.97 & 1.53 & 4.25 & 2.72 & 0.37 \\
\hline b-enol2 & -7.09 & -1.57 & 5.53 & 7.09 & 1.57 & 4.33 & 2.76 & 0.36 \\
\hline b-keto & -6.94 & -1.62 & 5.32 & 6.94 & 1.62 & 4.28 & 2.66 & 0.38 \\
\hline c-enol & -6.20 & -1.19 & 5.01 & 6.20 & 1.19 & 3.69 & 2.50 & 0.40 \\
\hline c-enol2 & -6.43 & -1.22 & 5.21 & 6.43 & 1.22 & 3.83 & 2.60 & 0.38 \\
\hline c-keto & -6.13 & -1.29 & 4.84 & 6.13 & 1.29 & 3.71 & 2.42 & 0.41 \\
\hline d-enol & -6.31 & -1.27 & 5.04 & 6.31 & 1.27 & 3.79 & 2.52 & 0.40 \\
\hline d-enol2 & -6.53 & -1.29 & 5.24 & 6.53 & 1.29 & 3.91 & 2.62 & 0.38 \\
\hline d-keto & -6.07 & -1.19 & 4.88 & 6.07 & 1.19 & 3.63 & 2.44 & 0.41 \\
\hline e-enol & -6.19 & -1.15 & 5.04 & 6.19 & 1.15 & 3.67 & 2.52 & 0.40 \\
\hline e-enol2 & -6.37 & -1.20 & 5.18 & 6.37 & 1.20 & 3.78 & 2.59 & 0.39 \\
\hline e-keto & -6.20 & -1.23 & 4.97 & 6.20 & 1.23 & 3.72 & 2.48 & 0.40 \\
\hline f-enol & -6.19 & -1.16 & 5.04 & 6.19 & 1.16 & 3.68 & 2.52 & 0.40 \\
\hline f-enol2 & -6.38 & -1.20 & 5.18 & 6.38 & 1.20 & 3.79 & 2.59 & 0.39 \\
\hline f-keto & -6.20 & -1.24 & 4.96 & 6.20 & 1.24 & 3.72 & 2.48 & 0.40 \\
\hline g-enol & -6.26 & -1.90 & 4.35 & 6.26 & 1.90 & 4.08 & 2.18 & 0.46 \\
\hline g-enol2 & -6.43 & -1.92 & 4.51 & 6.43 & 1.92 & 4.18 & 2.26 & 0.44 \\
\hline g-keto & -6.28 & -2.05 & 4.23 & 6.28 & 2.05 & 4.17 & 2.11 & 0.47 \\
\hline h-enol & -6.18 & -1.22 & 4.97 & 6.18 & 1.22 & 3.70 & 2.48 & 0.40 \\
\hline h-enol2 & -6.44 & -1.26 & 5.17 & 6.44 & 1.26 & 3.85 & 2.59 & 0.39 \\
\hline h-keto & -6.27 & -1.28 & 4.99 & 6.27 & 1.28 & 3.77 & 2.49 & 0.40 \\
\hline i-enol & -6.23 & -1.21 & 5.03 & 6.23 & 1.21 & 3.72 & 2.51 & 0.40 \\
\hline i-enol2 & -6.41 & -1.25 & 5.15 & 6.41 & 1.25 & 3.83 & 2.58 & 0.39 \\
\hline i-keto & -6.26 & -1.32 & 4.94 & 6.26 & 1.32 & 3.79 & 2.47 & 0.40 \\
\hline
\end{tabular}

The calculated HOMO-LUMO gap for the triazolopyrimidinone molecule $\mathbf{g}$ turned out to be the smallest among all studied compounds and was $4.23 \mathrm{eV}$. What is more, in the case of all molecules, HLG for keto-tautomers turned out to be the smallest in comparison with the corresponding enol tautomers. 


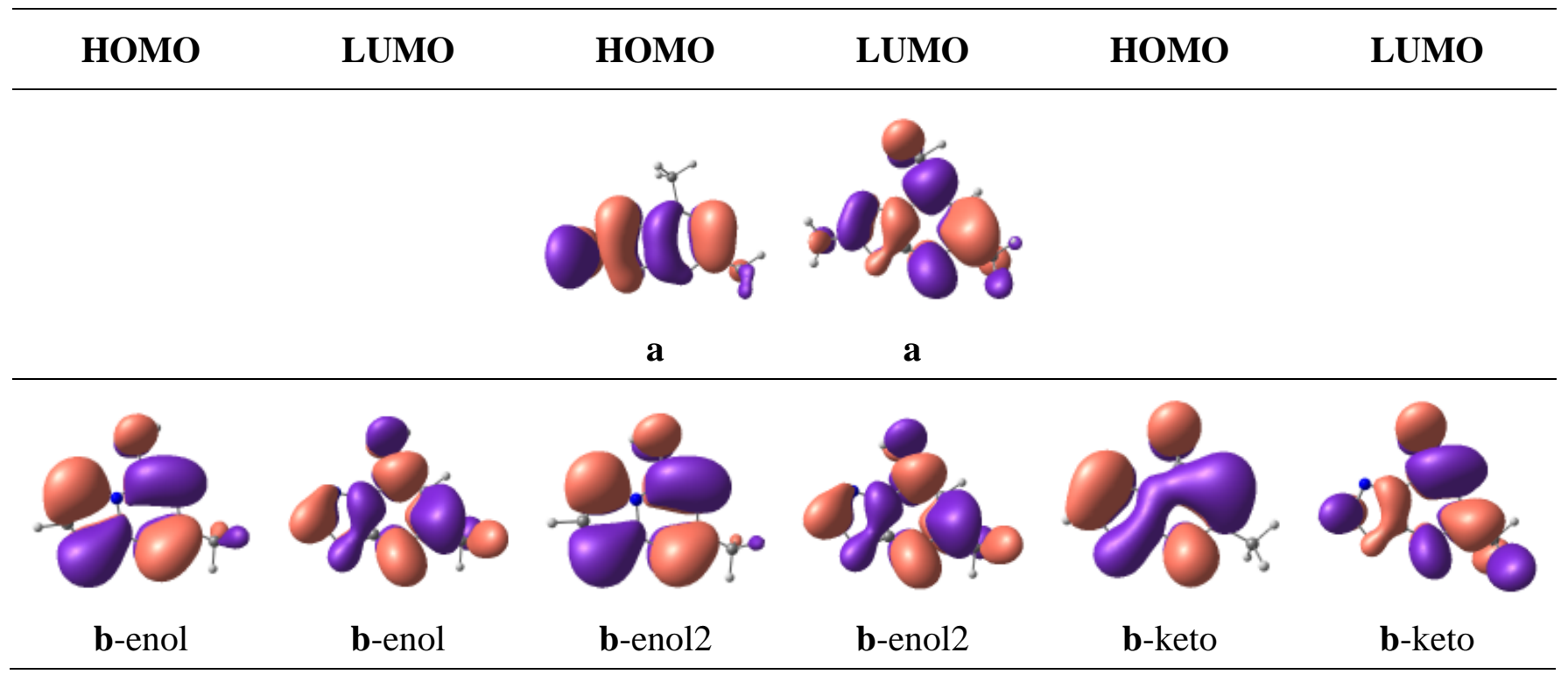

Figure 6. Molecular orbitals of the $\mathbf{a}-\mathbf{b}$ molecules.

Among all the substances studied, the molecule of compound $\mathbf{b}$ showed the highest HLG of $5.32 \mathrm{eV}$. This suggests that even though the exocyclic amino group is not the key moiety that provides metal passivation, it makes a significant contribution to the overall reactivity of molecules and their formation of protective layers on the metal surface. A similar trend was observed for the absolute hardness index: the lowest values were characteristic of structure $\mathbf{g}$, the highest were characteristic of structure b. In other words, triazolopyrimidinone $\mathbf{g}$ is the most prone to chemical interactions. Other compounds are similar in this indicator.

The results of quantum-chemical calculations were used to show that the inhibitory activity is largely due to the presence of NH-protons of pyrimidine moieties. Earlier, researchers studied the effect of triazolopyrimidine-6-carboxylate compounds on copper passivation [17]. It was established that such structures with a triazolopyrimidine matrix must be forming protective layers on the metal surface as a result of the formation of complexes with the atoms of the metal surface with the participation of the $\mathrm{NH}$ proton of the dihydropyrimidine cycle [18]. In this case, a similar effect must be taking place: the studied compounds form complex compounds, whose estimated structures are shown in Figure 8.

The formation of such adsorbed layers on a metal surface was previously described in detail using the example of 3-alkyl-5-amino-1H-[1,2,4]-triazoles [19]. The authors used physical methods to show that the adsorption capacity of triazole molecules increases with an increase in the mobility of endocyclic NH-protons, as well as with the introduction of hydrophobic substituents into the cycle. It was noted that the latter factor can have a negative effect on the adsorption properties of inhibitors when using long-chain and branched substituents due to steric difficulties and the deterioration of solubility. Thus, within the framework of this study, a similar inhibition mechanism was observed. However, it involved the participation of $\mathrm{NH}$-protons of the pyrimidine cycle condensed with the triazole cycle. 


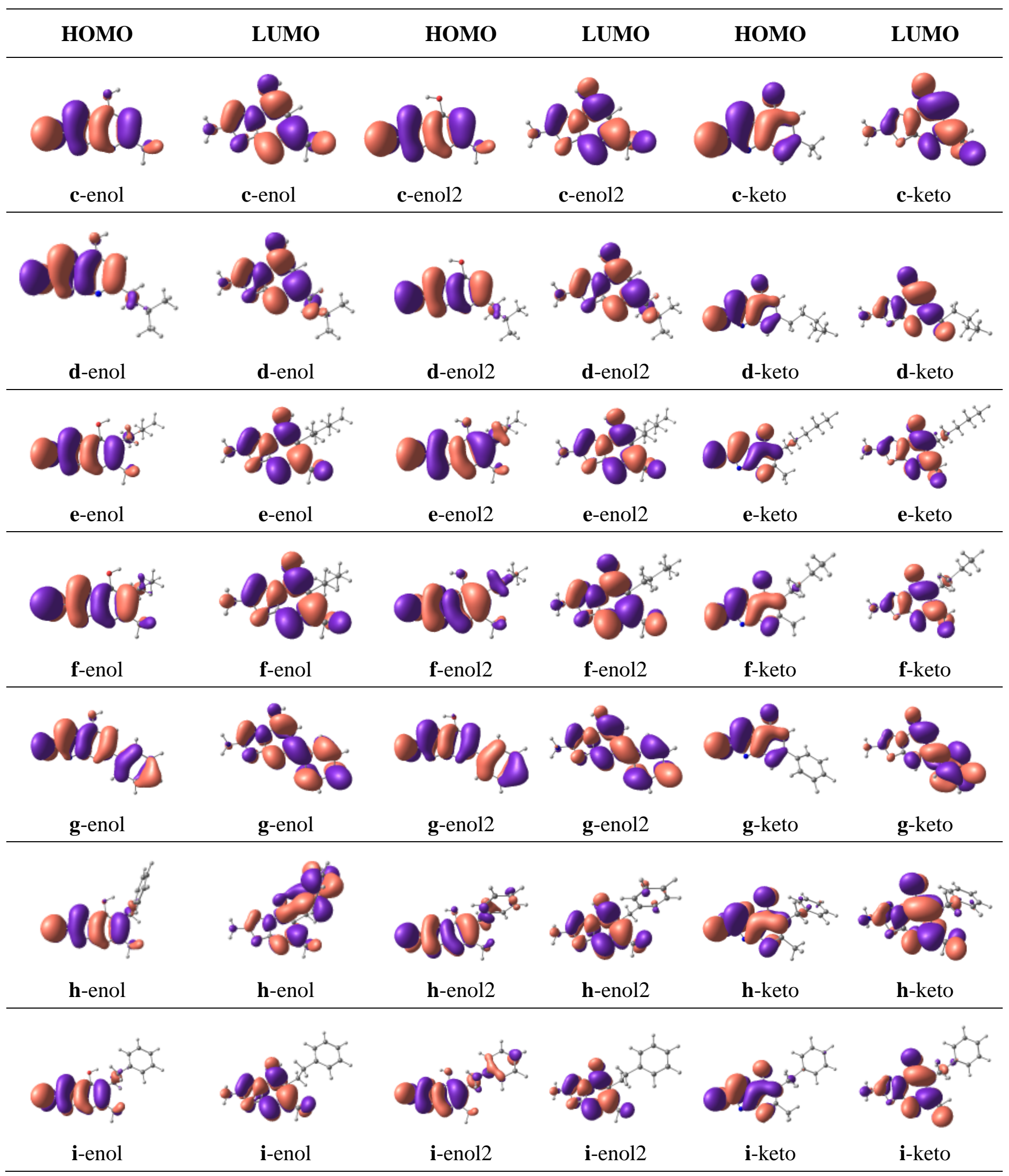

Figure 7. Molecular orbitals of the $\mathbf{c}-\mathbf{i}$ molecules. 


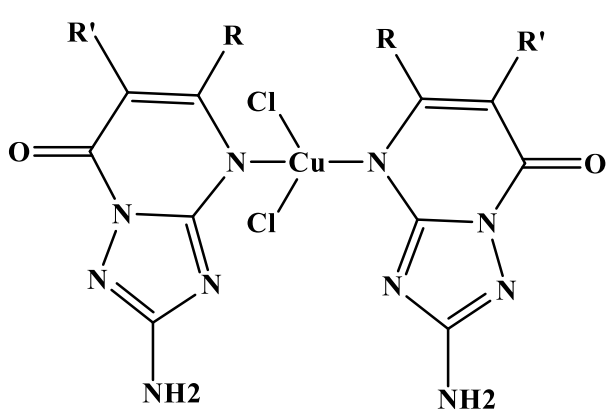

Figure 8. Complex based on $[1,2,4]$ triazolo $[1,5-a]$ pyrimidin-7-ones with $\mathrm{Cu}^{2+}$ ions.

It was found that the best protective properties were characteristic of inhibitors containing aliphatic branched butyl, phenethyl, isopentyl substituents (triazoles $\mathbf{f}, \mathbf{i}$, and $\mathbf{d}$ ), which is in line with previous studies, theoretical DFT calculations, and the literature data. According to the calculated data, compounds $\mathbf{g}$ and $\mathbf{h}$, containing phenyl moieties in their structures, should also exhibit high protective indicators. However, their low solubility in water causes a discrepancy with the calculated indicators for these inhibitors.

\section{Conclusion}

In our study we used full-scale electrochemical and quantum chemical methods to analyse the inhibitory properties of new synthesised derivatives of $[1,2,4]$ triazolo[ $[1,5-a]$ pyrimidine7-ones with regard to the corrosion of copper in neutral and acidic chloride environments with concentrations of $\sim 0.01-1.00 \mathrm{mM}$.

The highest degree of protection in a neutral environment was obtained at a concentration of $1.00 \mathrm{mM}$ of 2-amino-5-isopentyl-[1,2,4]triazolo[1,5- $a$ ]pyrimidine-7(4H)one d $(90 \%)$ and 2-amino-5-methyl-6-phenethyl-[1,2,4]triazolo[1,5- $a$ ]pyrimidine-7(4H)one $\mathbf{i}(85 \%)$, as well as at a concentration of $0.10 \mathrm{mM}$ of 2-amino-6-butyl-5-methyl$[1,2,4]$ triazolo[1,5- $a]$ pyrimidine-7(4H)-one $\mathbf{f}(81 \%)$. In an acidic environment, the most effective inhibitors were the same compounds, $\mathbf{d}, \mathbf{i}$, and $\mathbf{f}$. However, as a result, the protection indicators were $68 \%, 71 \%$, and $73 \%$, respectively. This class of compounds is a more effective corrosion inhibitor for copper in a neutral chloride environment than in an acidic environment.

The article suggests and justifies the protection mechanism of the studied inhibitors, which involves their chemosorption on the metal's surface and formation of self-organising protective layers as a result of the complex formation process with the participation of endocyclic NH-protons of the pyrimidine cycle. Such an interaction is typical of ketotautomers of the studied substances.

\section{Acknowledgements}

The study was supported by the Russian Foundation for Basic Research, project no. 20-3380017. Analytical research was done using equipment of NRC "Kurchatov Institute" - IREA Shared Knowledge Center. 


\section{References}

1. S.G. Bullard, B.J. Gromek, M. Fout and R. Fout, The Silver Bridge Disaster of 1967, Arcadia Publishing, 2012, p. 128.

2. R.W. Revie, Corrosion and corrosion control: an introduction to corrosion science and engineering, John Wiley \& Sons, 2008, p. 512. doi: 10.1002/9780470277270

3. V.S. Sastri, Corrosion Inhibitors: Principles and Applications, Wiley, New York, 1998, p. 926.

4. V.S. Sastri, Green Corrosion Inhibitors: Theory and Practice, Wiley, New Jersey, 2012, p. 328. doi: 10.1002/9781118015438

5. C. Verma, E.E. Ebenso and M.A. Quraishi, Corrosion inhibitors for ferrous and nonferrous metals and alloys in ionic sodium chloride solutions: A review, J. Mol. Liq., 2017, 248, 927-942. doi: $10.1016 /$ j.molliq.2017.10.094

6. Yu.I. Kuznetsov and L.P. Kazansky, Physicochemical aspects of metal protection by azoles as corrosion inhibitors, Russ. Chem. Rev., 2008, 77, 219-232. doi: 10.1070/RC2008v077n03ABEH003753

7. Yu.I. Kuznetsov, A. D. Mercer and J. G. N. Thomas, Organic inhibitors of corrosion of metals, Springer Science \& Business Media, 1996. doi: 10.1007/978-1-4899-1956-4

8. S. Lahmidi, A. Elyoussfi, A. Dafali, H. Elmsellem, N.K. Sebbar, L.El Ouasif, A.E. Jilalat, B.El Mahi, E.M. Essassi, I. Abdel-Rahman and B. Hammouti, Corrosion inhibition of mild steel by two new 1,2,4-triazolo [1,5-a] pyrimidine derivatives in $1 \mathrm{M}$ HCl: Experimental and computational study, J. Mater. Environ. Sci., 2017, 8, 225-237. https://www.jmaterenvironsci.com

9. I.R. Saad, A.M. Abdel-Gaber, G.O. Younes and B. Nsouli, Corrosion Inhibition of Mild Steel in Acidic Solutions Using 1,2,4-Triazolo [1,5-a] pyrimidine, Russ. J. Appl. Chem., 2018, 91, 245-252. doi: $10.1134 / S 107042721802012 \mathrm{X}$

10. D.S. Shevtsov, M.N.M. Mawlood, O.A. Kozaderov, Kh.S. Shikhaliev, A.A. Kruzhilin, A.Yu. Potapov, I.D. Zartsyn and Ch. Prabhakar, New copper corrosion inhibitors in chloride environments based on benzo-[1,2,4]-triazolo-[1,2]-triazinones, Int. J. Corros. Scale Inhib., 2021, 10, no. 1, 228-244. doi: 10.17675/2305-6894-2021-10-1-13

11. E. Bardez, I. Devol, B. Larrey and B. Valeur, Excited-state processes in 8hydroxyquinoline: photoinduced tautomerization and solvation effects, J. Phys. Chem. $B, 1997,101,7786-7793$. doi: $10.1021 / \mathrm{jp} 971293 \mathrm{u}$

12. F. Mansfeld, Tafel slopes and corrosion rates obtained in the pre-Tafel region of polarisation curves, Corros. Sci., 2005, 47, 3178-3186. doi: $10.1016 /$ j.corsci.2005.04.012

13. M.J. Frisch, G.W. Trucks, H.B. Schlegel, G.E. Scuseria, M.A. Robb, J.R. Cheeseman, G. Scalmani, V. Barone, G.A. Petersson and H. Nakatsuji, Gaussian16 Revision B.01, Gaussian Inc. Wallingford CT, 2016. https://gaussian.com/g16main/

14. R.G. Parr and R.G. Pearson, Absolute hardness: companion parameter to absolute electronegativity, J. Am. Chem. Soc., 1983, 105, 7512-7516. doi: 10.1021/ja00364a005 
15. C.G. Dariva and A.F. Galio, Corrosion inhibitors - principles, mechanisms and applications, Dev. Corros. Prot., 2014, 16, 365-378. doi: 10.5772/57255

16. M.A. Quraishi, D.S. Chauhan and V.S. Saji, Heterocyclic organic corrosion inhibitors: principles and applications, Elsevier, 2020, p. 298. doi: 10.1016/C2018-0-04237-1

17. A.A. Kruzhilin, V.A. Polikarchyuk, O.A. Kozaderov, Kh.S. Shikhaliev, D.S. Shevtsov, A.Yu. Potapov, I.D. Zartsyn and C. Prabkhakar, New copper corrosion inhibitors in chloride environments based on $[1,2,4]$ triazolo[1,5-a]pyrimidine-6-carboxylates, Int. J. Corros. Scale Inhib., 2021, 10, 732-748. doi: 10.17675/2305-6894-2021-10-2-16

18. L. Yang, L. He, J. Zhang, S. An and L. Zhang, Exploring the copper (II)-aminotriazole complex-binding sites of human serum albumin, J. Biol. Inorg. Chem., 2015, 20, 1059-1068. doi: 10.1007/s00775-015-1287-X

19. Yu.I. Kuznetsov, Kh.S. Shikhaliev, M.O. Agafonkina, N.P. Andreeva, A.M. Semiletov, A.A. Chirkunov, A.Yu. Potapov and V.E. Solov'ev, Formation of passivating layers by 1,2,4-triazole derivatives on copper in aqueous solutions, Russ. J. Phys. Chem., 2017, 91, 2458-2465. doi: $10.1134 / \mathrm{S} 0036024417120147$ 